\title{
Cinnamomum Essential Oil Prevents DNA Damage-Induced by Doxorubicin on CHO-KI Cells
}

\author{
Layung Sekar Sih Wikanthi, Nindi Wulandari, Yuni Fajar Esti, Nur Fitra Sari, Ratna \\ Asmah Susidarti*
}

Cancer Chemoprevention Research Center, Faculty of Pharmacy, Universitas Gadjah Mada

\begin{abstract}
DNA damage usually happens due to the several chemical materials that induce genotoxic effect in normal cells. Cinnamon essential oil (CEO), which contains cinnamaldehyde as its major compound, has been reported to possess antioxidant activity to prevent DNA damage. The aim of this study is to evaluate the genotoxic and cytotoxic effect of CEO on doxorubicin-induced Chinese Hamster Ovary $(\mathrm{CHO}-\mathrm{KI})$ cells. The cytotoxic effect of CEO was determined by MTT assay with the parameter of $\mathrm{IC}_{50}$ while the genotoxic effect was carried out by micronucleus (MN) assay by using acridine orange fluorescent staining with the parameter of $\mathrm{MN} / \mathrm{I} 000$ cells reduction number. Based on MTT assay, CEO showed cytotoxic activity with the $\mathrm{IC}_{50}$ value of $30 \mu \mathrm{g} / \mathrm{mL}$ and for $\mathrm{MN}$ assay, $3 \mu \mathrm{g} / \mathrm{mL}\left(1 / 10 \mathrm{IC} \mathrm{C}_{50}\right)$ of CEO decreased the percentage of micronucleus per 1000 cells up to $94.55 \%$. Thus, the result can be summarized that CEO does not induce genotoxic and has the potency to prevent DNA damage caused by doxorubicin on CHO-KI cells.
\end{abstract}

Keywords: genotoxic, cinnamomum essential oil (CEO), micronuclei assay, in vitro

\section{INTRODUCTION}

Genotoxic compounds are widely known to interact with DNA/RNA, causing disrupt genetic codes in the chromosome (Guengerich, 1992). Carcinogens, mutagens or teratogens cause genetic mutation in cells and other biological systems (Shah, 2012). Moreover, genotoxic compounds also lead to various degenerative diseases such as cancer, atherosclerosis, arthritis, neurodegenerative disorders and other serious diseases (Bonassi, et al., 2011).

Development of antigenotoxic agent could reduce genotoxicity. Some natural product have potential as antigenotoxic agent, suc as Cinnamomum burmannii. The major compound of C. burmannii, cinnamaldehyde, has been explored in several studies as antioxidant (Al-Dhubiab, 2012). C. burmannii extract was reported to inhibit lipopolysaccharide-induced nitric oxide release and showed antioxidant activity on RAW264.7 cell, possibly mediated through the evaluation of free radical scavenging activity and reducing power (Choi, et al., 2005).

The aim of this study was to evaluate the antigenotoxic activity of cinnamon essential oil (CEO) using CHO-K1 cells induced by doxorubicin.
This study is expected to be a scientific reference prevent degenerative diseases through inhibition og genotoxic effects.

\section{MATERIALS AND METHODS}

\section{Sample Preparation}

The bark of $C$. burmanii were collected from Yogyakarta and determined in Pharmacognosy Laboratory, Faculty of Pharmacy Universitas Gadjah Mada. CEO was extracted using steam-destilation method. Briefly, $3 \mathrm{~kg}$ of $C$. burmannii was placed in large metal vessel. Destilation occurred for 5 hours and CEO was collected. CEO then dissolved in Dimethyl Sulfoxide (DMSO) (Sigma) for further experiment using cells culture.

*Corresponding author e-mail: susidarti@yahoo.com 


\section{Cell culture}

CHO-K1 cells were obtanined from Cancer Cancer Chemoprevention Research Center, Yogyakarta. The cells were maintained in RPMI medium (Gibco), supplemented with 10\% \% $/ \mathrm{v}$ Fetal Bovine Serum (FBS) (Sigma) and $1 \% \quad 10.000$ unit/ml Penicillin-Streptomycin.

Cell were routinely grown in $10 \mathrm{~cm}^{2}$ tissue culture disk and kept in a humidified atmosphere of $5 \% \mathrm{CO}_{2}$ at $37^{\circ} \mathrm{C}$. Cells were harvested with a solution of $0.25 \%$ Trypsin-EDTA (Gibco) when they were in a log phase of growth, and maintained at the above-described culture conditions for all experiments.

\section{Cell viability assay}

Cell viability was determined using MTT assay as performed by Mosmann (1983) with slight modification. Cells were seeded into a 96-well plate (briefly 8000 cells per well) and incubated for $24 \mathrm{~h}$. After rinsing the cells using PBS, cells were treated with various concentration of $\mathrm{CEO}$ and doxorubicin. Certain concentration of either single or combination of samples were the applied. After $24 \mathrm{~h}$ incubation, MTT reagent [3-(4,5-dimethyl-2.thiazolyl)2,5diphenyltetrazolium bromide in PBS $(5 \mathrm{mg} / \mathrm{mL})]$ was added $100 \mu \mathrm{L}$ to each well. The plate was incubated in a humidified atmosphere of $5 \% \mathrm{CO}_{2}$ at $37^{\circ} \mathrm{C}$ for $3 \mathrm{~h}$, until formazan crystals was formed before dissolved in $100 \mu \mathrm{L}$ of stopper reagent with $0.01 \mathrm{~N} \mathrm{HCl}$ and incubated in dark place for overnight. The absorbance of cells was measured at $595 \mathrm{~nm}$ using microplate reader. The data was a presented as percentage of viable cells $(\%)$.

\section{Acridine orange staining}

Cells $\left(1.2 \times 10^{4}\right.$ cells/well $)$ were seeded on coverslip in 24 well plates until $80 \%$ confluent. Cells were then incubated $16-24 \mathrm{~h}$, then medium was replaced with PBS. Medium and reagents were added in the well, then incubated for 28 hours. Cells were treated with sample for $24 \mathrm{~h}$ at $37^{\circ} \mathrm{C}$ as described previously. The next day, the media was discarded then the cells were washed using PBS. Cells were fixed by methanol, and stained by acridine orange. The stained cells then were observed under fluoresence microscope with 100x magnification.

\section{RESULT AND DISCUSSION}

\section{CEO showed Antiproliferative Activity}

Cell viability assay was conducted to determine using MTT assay. Based on the result, single treatment of CEO and doxorubicin inhibited cells growth in dose dependent manner after treated for $24 \mathrm{~h}$. The $\mathrm{IC}_{50}$ value of CEO and DOX respectively $30 \mu \mathrm{g} / \mathrm{mL}$ and $30 \mu \mathrm{M}$.

\section{CEO Reduced the Genotoxic Effect of Doxorubicin}

Based on the result, CEO at the concentration of $3 \mu \mathrm{g} / \mathrm{mL}\left(1 / 10 \mathrm{IC}_{50}\right)$ was able to reduce genotoxic effect of doxorubicin on CHO-K1 cells. The green fluorescence indicated the expression of viable cells, while the small bright spot inside the viable cells indicated the micronucleus. The decreasing of micronucleus number was related to the suppression of genotoxic effect.

When CEO $(3 \mu \mathrm{g} / \mathrm{mL})$ was in combination with doxorubicin $(15 \mu \mathrm{M})$ showed significantly suppression of micronuclei number compared the single treatment of doxorubicin. Therefore, CEO was able to reduce the genotoxic effect from doxorubicin on $\mathrm{CHO}-\mathrm{K} 1$ cells. 


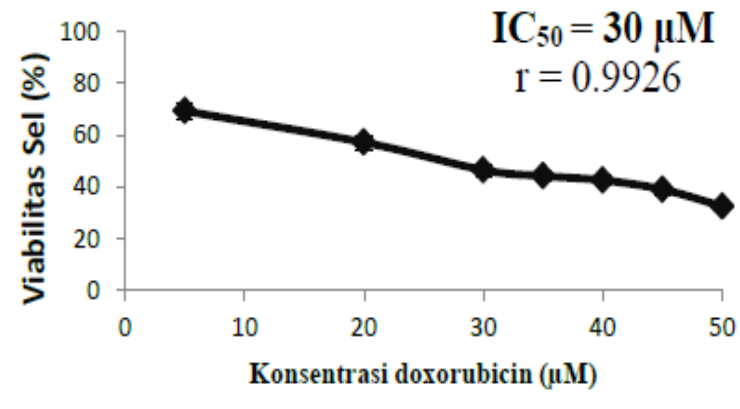

A

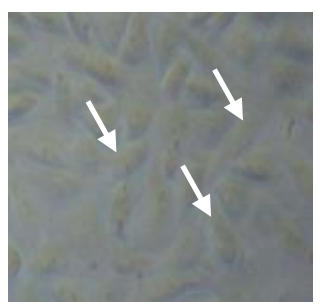

C

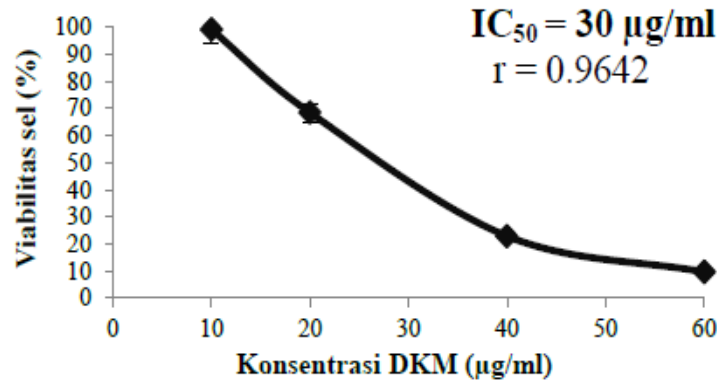

B

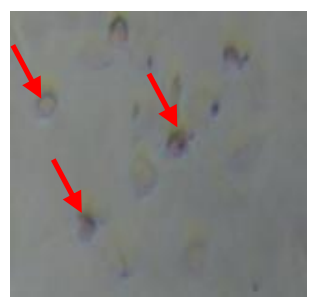

D

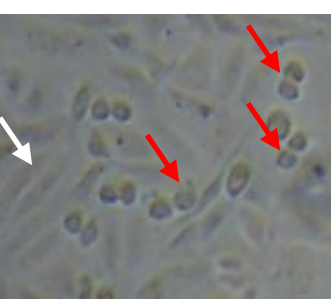

$\mathbf{E}$

Figure I. Cell viability assay of CEO. Briefly, 8,000 CHO-KI cells/well were incubated for $24 \mathrm{~h}$ before treated with CEO and doxorubicin for $24 \mathrm{~h}$. MTT assay was carried out as mentioned in methods then the absorbance was determined using a microplate reader. Cell viability profile after single treatment of doxorubicin (A) and CEO (B). The cells morphology of control cell (C), $8 \mu \mathrm{M}$ of doxorubicin (D), and $20 \mu \mathrm{g} / \mathrm{mL}$ of CEO (E) on CHO-KI cells after $24 \mathrm{~h}$ of treatment. Cells photo was captured with 100x magnification which showed morphological changes in cells. The red arrow show the morphological changes in cells, while white arrow show the normal cells. 

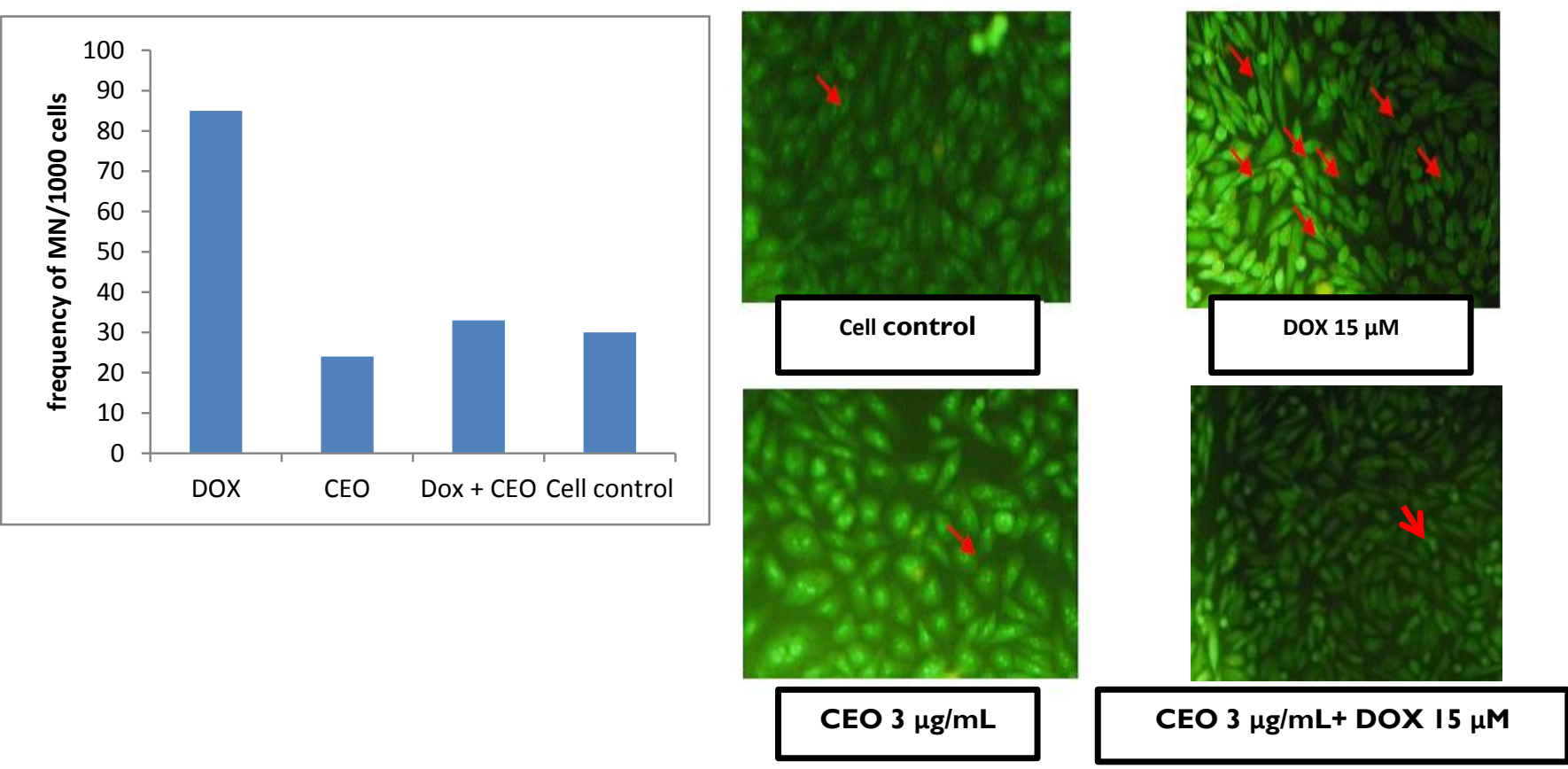

Figure 2. CEO Suppression of micronuclei in CHO-KI Cells. Visualization micronuclei determined by akridin orange staining and observed under fluoresence microscope.

\section{DISCUSSION}

Genotoxic compounds are widely known to interact with DNA/RNA, causing disrupt genetic codes in chromosome (Guengerich, 1992). Genotoxicity is determined by micronucleic which formed inside the cells when the cells was divided incompletely due to the DNA damage. The damage caused the gene was unable went towards the spindle thread when mitosis was occured. As the result, in telophase stage, the nuclear membrane was formed which covered the defective chromosome DNA and formed a small nucleus fragment called micronucleus (Zhou, et al., 2000).

Cinnamommum burmanii has been known to have antioxidant activity. CEO was expected to inhibit genotoxicity process and reduce the micronucleus. Single cytotoxic test demonstrated that $\mathrm{CEO}$ inhibited cells proliferation with $\mathrm{IC}_{50}$ value of $30 \mu \mathrm{g} / \mathrm{mL}$ while doxorubicin with $\mathrm{IC}_{50}$ value of $30 \mu \mathrm{M}$. Related studies has been carried out by Larasati (2013) whose using CEO on HeLa cells, given $\mathrm{IC}_{50}$ of $250 \mu \mathrm{g} / \mathrm{mL}$. Doxorubicin was used as the model of genotoxic effect in this study due to previous studies have been reported that the drug is a potent genotoxic anticancer drug that generates undesirable effect in health cells by creating reactive oxygen species (ROS) (Shi, et al., 2005). From this study, it can be seen that CEO has been able to reduce the micronuclei score in CHO-K1 cells. The extracts of $C$. burmannii was reported to inhibit lipo-polysaccharide-induced nitric oxide release and showed antioxidant activity on RAW264.7 cell, possibly mediated through the evaluation of free radical scavenging effect and reducing power (Choi, et al., 2005). Therefore, CEO possesses its potential as antigenotoxic agent through antioxidant activity.

\section{CONCLUSION}

CEO inhibit the genotoxic effect of doxorubicin and reduce the micronucleus score on CHO-K1 cells, thus CEO is potential to be developed as an antigenotoxic agent. 


\section{REFERENCES}

Al-Dhubiab, B.E., 2012, Pharmaceutical Applications and Phytochemical Profile of Cinnamomum burmannii, Pharmacog. Rev., 6(I2), |25-|3|.

Bonassi, S., Coskun, E., Ceppi, M., Lando, C., Bolognesi, C., Burgaz, S., et al., 20II, The HUman MicroNucleus project on eXfoliated buccal cells (HUMN XL): the role of life-style, host factors, occupational exposures, health status, and assay protocol, Mutat. Res., 728(3), 88-97.

Choi, E.M. and Hwang, J.K., 2005, Screening of Indonesian Medicinal Plants for Inhibitor Activity on Nitric Oxide Production of RAW264.7 cells and antioxidant activity, Fitoterapia, 76(2), 194-203.
Guengerich, FP., 1992, Metabolic Activation of Carcinogens, Pharmacol. Ther., 54(I), I7-6I.

Shah, S.U., 2012, Importance of Genotoxicity \& S2A guidelines for genotoxicity testing for pharmaceuticals, IOSR J. Pharm. Biol. Sci., I (2), 2278-3008.

Shi, M., Xu, B., Azakami, M., Morikawa, T., Watanabe, K., Morimoto, K., et al., 2005, Dual Role of Vitamin C in An Oxygensensitive System: Discrepancy between DNA Damage and Cell Death, Free Radic. Res., 39(2), 213-220.

Zhou, B.B. and Elledge, S.J., 2000, The DNA Damage Response: Putting Checkpoints in Perspective, Nature, 408(68I I), 433-439. 